* Mestrando em Direito, Democracia e Sustentabilidade do PPG/IMED, vinculado à linha de pesquisa 2 - Mecanismos de efetivação dos direitos fundamentais. Bolsista CAPES (modalidade Taxa). Graduado em Direito pela Faculdade Meridional IMED. Bolsista desempenho. Advogado. E-mail: bruno dellagerisi@hotmail.com

** Doutor (2013) e mestre (2010) em Direito Público - UNISINOS (Capes 6), além de especialista em Direito Tributário - UPF (2006). Pesquisador na área da Hermenêutica Jurídica, Argumentação Jurídica, Direitos Fundamentais, Teoria do Direito, Direito Constitucional, e Direito e Literatura. Docente da Escola de Direito e do PPGD da Faculdade Meridional IMED/Passo Fundo. Exerce a advocacia na área tributária, previdenciária, cível e eleitoral. E-mail: faustosmorais@gmail.com

\section{Modulação e abstrativização do efeito difuso: estudo de caso}

\author{
Modulation AND ABSTRATIVIZAÇÃo DIFFUSE \\ EFFECT: CASE STUDY \\ * Bruno Ortigara Dellagerisi Correio \\ ** Fausto Santos de Morais
}

Resumo: O presente artigo tem como finalidade discutir, a partir da modulação dos efeitos da decisão no controle de constitucionalidade, a possibilidade de atuação discricionária do Poder Judiciário. Apresentados os controles de constitucionalidade difuso e concentrado, bem como a modulação dos efeitos da decisão que reconhece a (in)constitucionalidade, parte-se para análise de um caso concreto, a saber, o Recurso Extraordinário 197.917/SP, em que o Supremo Tribunal Federal modulou os efeitos de sua decisão. Mesmo se tratando de controle difuso de constitucionalidade, onde se adota a teoria da nulidade, o Supremo Tribunal Federal decidiu pela aplicação de efeitos pro futuro, oriundo do controle concentrado de constitucionalidade. Assim, utilizando-se do método fenomenológico-hermenêutico, parte-se da premissa básica de que a abstrativização do efeito difuso pode ser maléfica a toda a sociedade. Desta premissa inicial, surgem algumas conclusões, dentre as quais a de que aqueles que não fizeram parte da lide e não tiveram direito ao contraditório e a ampla defesa podem sofrer os efeitos da decisão. Conclui-se também, que a modulação parece indicar uma postura ativista do Poder Judiciário, que, sem critérios explícitos para definição dos efeitos das suas decisões, controlam a constitucionalidade posta em discussão.

Palavras-chave: Abstrativização; Controle de Constitucionalidade; Discricionariedade; Modulação.

Abstract: This article aims to discuss, from de decision's effects modulation on the constitutionality control, the possibility of discretionary action of the Judiciary. Submitted the diffuse and concrete constitutionality controls, as well as the decision's effects modulation that recognize the (un)constitutionality, it follows for a concrete case analysis, the Extraordinary Appeal 197.917/SP, in which the Supreme Federal Court has modulated their decision's effects. Even dealing about diffuse constitutionality control, where is adopted the theory of nullity, the Supreme Federal Court has decided by applying the "for the future effect", arised from the concrete constitutionality control. Thus, using the phenomenological-hermeneutic method, 
part on the basic premise that the diffuse effect abstraction may be maleficent to the whole society. From this initial premise some conclusions arises, among wich that those who did not were part of the lawsuit and had no right to the contradictory and full defense may suffer the decicion's effects. It also concludes, that the modulation seem to indicate an activist stance of the Judiciary, which without explicit criteria for their decisions's effects definition, control the constitucionality disposed into discussion.

Keywords: Abstraction; Constitutionality Control; Discretion; Modulation. 


\section{INTRODUÇÃO}

Quais são os efeitos da declaração de (in)constitucionalidade in concreto? Pode o Supremo Tribunal Federal modular os efeitos de sua decisão no controle difuso de constitucionalidade? Partindo-se destes problemas de pesquisa, a hipótese é de que a modulação pode abrir uma margem para $o$ poder judiciário atuar de maneira discricionária, e, portanto, sem critérios constitucionais.

Dividido em quatro seções, sendo que cada uma delas representa um objetivo específico, este artigo apresenta a modulação dos efeitos no controle de constitucionalidade. Para tanto, antes de trabalhar com a modulação, é necessário trazer a discussão para a seara do constitucionalismo contemporâneo.

Assim, a primeira seção trata sobre a superação do positivismo jurídico pelo constitucionalismo contemporâneo, através do surgimento de constituições rígidas e hierarquicamente superiores ao restante do ordenamento jurídico. A segunda seção trata sobre o controle de constitucionalidade, trazendo as características dos modelos difuso e concentrado.

A terceira seção trata sobre a questão da modulação no controle de constitucionalidade, apresentando, ao final, a abstrativização do controle difuso, ou seja, da possibilidade de aplicar efeitos prospectivos (o que é característica do controle abstrato) a decisão de inconstitucionalidade via controle concentrado. Com este suporte teórico, parte-se para a quarta e última seção, onde se analisa um caso que o STF aplicou a chamada abstrativização do controle difuso.

Para dar conta da pesquisa, utiliza-se o método fenomenológico hermenêutico ${ }^{1}$ procurando entender como o objeto em estudo é apresentado pela doutrina, em especial os ensinamentos de Lenio Streck, e pela jurisprudência pátria.

\section{APRESENTANDO O CONSTITUCIONALISMO CONTEM- PORÂNEO}

Com a passagem do Estado Totalitário para o Estado Democrático de Direito surge a necessidade de uma nova Teria do Direito, haja vista que com a queda dos regimes nazistas e fascista na Europa pós II Guerra, e a consequente

\footnotetext{
${ }^{1} \mathrm{O}$ método fenomenológico hermenêutico permite explorar o objeto da pesquisa através da constante revisão. Assim, uma premissa que no início da pesquisa se apresentava como essencial, pode perder importância com o aprofundamento teórico.
} 
"desvalorização" do positivismo jurídico, cresce a preocupação com a legitimidade do Direito.

Com isso, supera-se o positivismo jurídico, e vive-se o denominado Constitucionalismo Contemporâneo, isso porque o Direito deixa de ser visto como um aglomerado de normas a serem aplicadas conforme a vontade (discricionariedade) do intérprete. Para o Constitucionalismo Contemporâneo, uma decisão legítima é aquela que se adéqua a Teoria das Fontes, Teoria da Norma e Teoria da Interpretação.

Esta nova forma de "pensar o Direito" traz de volta perspectivas novas para o Direito, esquecidas pelo Positivismo, como a filosofia e a hermenêutica jurídica. Também, para a consolidação de um Estado Democrático de Direito é necessário entender que a Constituição passa a ser o centro normativo de todo o ordenamento Jurídico, reconhecendo a imperatividade do Direito e impondo limites ao legislador e ao administrador.

Historicamente, o Estado de Direito foi sendo consolidado ao longo do Século XIX, e ao final deste, o Direito Constitucional se desenvolve na Europa, quando os regimes constitucionais passam a se impor sobre as monarquias absolutistas e os governos oligárquico-aristocráticos. Baseados nos ideais iluministas da razão, da contenção do poder e do respeito ao indivíduo, as revoluções francesa e americana instituem as primeiras Constituições modernas, materializadas em documentos escritos. (BARROSO, 2012, p.62)

Estas primeiras constituições escritas são compostas por normas de repartição e limitação de poder. Porém, apenas no séc. XX "foram completados os termos da complexa equação que traz como resultado o Estado democrático de direito: quem decide, como decide, o que pode e não pode ser decidido". (BARROSO, 2012, p. 62-63). Este tipo de organização estatal é centrado em dois principais conceitos: a) Democracia: que dá alma ao Estado. É o governo para todos; e b) Estado de Direito: que obedece a algum tipo de ordenamento legal. (BARROSO, 2012, p. 63).

Segundo Streck, o fenômeno do constitucionalismo contemporâneo possui como característica a existência de uma Constituição "extremamente embebedora", "capaz de condicionar tanto a legislação, quanto a jurisprudência e o estilo doutrinário, a ação dos agentes públicos e ainda influenciar as relações sociais", o que proporciona o surgimento de ordenamentos jurídicos constitucionalizados (STRECK, 2005, p.161).

Para Mendes, não foi por acaso que a Constituição se revestiu de um valor normativo supremo, pois o valor hoje atribuído à Constituição é resultado 
de "reflexões propiciadas pelo desenvolvimento da História e pelo empenho em aperfeiçoar os meios de controle do poder, em prol do aprimoramento dos suportes da convivência social e política" (MENDES, 2012, p. 58). Mendes ainda ensina que a Constituição se caracteriza pela absorção de valores morais e políticos, em um sistema de direitos fundamentais autoaplicáveis, com o poder emanado do povo e manifestado por seus representantes (2012, p. 58-59).

Este novo modelo de constitucionalismo confere superioridade à Constituição, a que se subordinam todos os poderes por ela constituídos, garantidos por mecanismos judiciais de controle de constitucionalidade (MENDES, 2012, p. 58), tendo em vista que a Constituição é o "centro de validade" do Direito. Em outras palavras, a Constituição é revestida de força normativa, porém, esta força normativa dependerá de uma adequada interpretação, permitindo que a política seja feita nos ditames constitucionais, ou seja, dando efetividade aos direitos fundamentais - sociais (STRECK, 2005, p.164).

Trindade destaca que o período pós Segunda Guerra serviu para o aprimoramento do Direito a partir de "novas propostas jusfilosóficas dispostas a reconhecer o fracasso do Direito, e repensar o seu sentido e vínculos com o agir humano, levando em conta a necessidade de se afirmar sua autonomia" (TRINDADE, 2012, p. 114).

Para Trindade, constitucionalismo contemporâneo é uma expressão que vem sendo usada para se referir às tentativas de explicar as transformações ocorridas no campo do direito a partir da Segunda Guerra Mundial, e que até hoje apresenta uma imprecisão terminológica e inúmeras divergências sobre o tema (TRINDADE, 2012, p. 96).

Essa dificuldade para delimita-lo alcança três níveis distintos. O primeiro deles é a promulgação de textos constitucionais na segunda metade do século $\mathrm{XX}$, contendo especificidades, normas que condicionam a atuação do Estado para a realização dos fins e objetivos estabelecidos. Passa pela posição assumida pelos tribunais constitucionais, utilizando parâmetros interpretativos compatíveis com o grau de racionalidade exigido das decisões judiciais. E, finalmente, chega na necessidade de estudar e compreender os novos textos constitucionais e aperfeiçoar a jurisprudência (TRINDADE, 2012, p. 96).

Porém, para este autor, "a ampliação do espaço da jurisdição, o grau de indeterminação do direito a partir da emergência dos princípios, e, o protagonismo dos juízes, afetam a relação entre direito e democracia" (TRINDADE, 2012, p. 97). 
Streck destaca que o Constitucionalismo Contemporâneo reúne ao mesmo tempo um forte conteúdo normativo, e as possibilidades garantidoras de direito a partir da jurisdição constitucional, residindo nesse ponto o cerne do constitucionalismo contemporâneo, pois isso gera, além dos tradicionais vínculos negativos (garantias contra a violação de direitos), obrigações positivas (direitos prestacionais). (STRECK, 2009, p.19)

Barroso ensina que por décadas o direito constitucional desempenhou um "papel programático e de convocação à atuação dos órgão públicos do que de um conjunto de normas imperativas de conduta" sendo que somente no estágio atual o constitucionalismo brasileiro assumiu uma dimensão normativista, ordenando e conformando a realidade social e política, impondo deveres e assegurando direitos (BARROSO, 2012, p. 69). Percebe-se que o Constitucionalismo Contemporâneo tem três marcos bem fixados, quais sejam, o histórico, o filosófico, e o teórico.

O marco histórico é o pós II Guerra Mundial, e, no Brasil, a promulgação da Constituição Federal, pois, como anteriormente dito, a partir da queda dos regimes totalitários exsurge a necessidade de uma nova Teoria do Direito. $\mathrm{O}$ marco filosófico reside na construção do pós-positivismo, voltando suas preocupações para a dignidade da pessoa humana e a legitimidade do Direito. Por fim, mas não menos importante, o marco teórico, que traz a força normativa da Constituição, a expansão da jurisdição constitucional e a reelaboração doutrinária da interpretação constitucional (BARROSO, 2012, p. 267-287).

\section{APRESENTANDO O CONTROLE DE CONSTITUCIO- NALIDADE}

O controle de constitucionalidade é um mecanismo de correção destinado a "alinhar" o ordenamento jurídico. Para tanto, duas premissas são identificadas como necessárias à existência do controle de constitucionalidade: a) a supremacia da constituição, e b) a rigidez constitucional (BARROSO, 2012, p.23-24). A primeira premissa revela a posição hierárquica superior da Constituição em relação aos demais ordenamentos jurídicos vigentes, sendo que nenhuma outra lei ou norma poderá existir em desconformidade com o texto constitucional, pois é a Constituição que valida todas as demais normas (BARROSO, 2012, p.23).

Já a segunda premissa para o controle de constitucionalidade, a rigidez constitucional, existe "para figurar como paradigma de validade dos demais atos normativos, a norma constitucional precisa ter um processo de elaboração 
diverso e mais complexo do que aquele apto a gerar normas infraconstitucionais" (BARROSO, 2012, p.24). Ou seja, para que a lei constitucional possa servir de objeto de controle, é necessário que a sua criação seja diferente daquele que cria a lei infraconstitucional, pois se igual o fossem, não haveria distinção entre a lei constitucional e a infraconstitucional, e, em caso de contrariedade, ocorreria a revogação do ato anterior e não a inconstitucionalidade (BARROSO, 2012, p.24).

O ordenamento jurídico brasileiro divide o controle de constitucionalidade das leis e dos atos do Poder Público ente o Controle Difuso e o Controle Concentrado, levando em consideração o órgão competente para realizar o controle. Também consagra duas formas de controle de constitucionalidade. São elas o Controle por via Incidental, e o Controle por via Principal.

Diz-se controle incidental, pois "a inconstitucionalidade é arguida no contexto de um processo ou ação judicial, em que a questão de inconstitucionalidade configura um incidente, uma questão prejudicial a ser decidida pelo julgador". (MENDES, 2012, p.1098).

O controle incidental, assim como o controle difuso, se da pela fiscalização da constitucionalidade por qualquer juiz ou tribunal, quando analisam casos levados à sua jurisdição. Como o próprio nome sugere, é uma questão a ser resolvida de forma incidental ao processo, e, tecnicamente, a questão constitucional figura como questão prejudicial ao processo de mérito, já que a (in)constitucionalidade da lei ou ato normativo não faz parte da causa de pedir (BARROSO, 2012, p.72).

Mesmo sendo institutos diferentes que não devem ser confundidos, o controle difuso e o controle incidental, via de regra, no Brasil, se superpõem, sendo que há muito tempo o controle incidental é exercido de forma difusa. Somente com o advento da ADCT, criada pela Lei n. ${ }^{\circ}$ 9.982, de 3 de dezembro de 1999, passou-se a admitir uma hipótese de controle incidental concentrado (BARROSO, 2012, p.73).

O Controle Difuso de constitucionalidade tem origem no caso estadunidense Marbury v. Madison, decidido pela Suprema Corte em 1803, e que acabou, mesmo que sem a intenção dos magistrados, se tornando o mais célebre caso constitucional de todos os tempos (BARROSO, 2012, p.25). A proclamação da supremacia da Constituição sobre as outras leis em Marbury v. Madison, e com o consequente poder dos juízes de não aplicar as leis inconstitucionais, certamente representou uma grande e importante inovação (CAPELETTI, 1984, p. 48). 
Foi na decisão deste caso que o juiz Marshall desenvolveu comentários sobre a supremacia da Constituição, da necessidade do judicial review (em que pese a Constituição não prever o poder de revisão aos juízes sobre atos do legislativo, o que deu início ao Ativismo Judicial por aquelas bandas (TASSARINI, 2012, p.14)), e a competência do judiciário sobre a matéria. Muito embora não ter sido pioneira e nem original, foi a partir deste caso que esta argumentação "ganhou o mundo e enfrentou com êxito resistências políticas e doutrinárias de matizes diversos" (BARROSO, 2012, p.27-28).

Em Marbury v. Madison, como bem destaca Capeletti, ficou assentado que ou a Constituição prepondera sobre os atos legislativos que com ela contrastam ou o poder legislativo pode mudar a Constituição através de lei ordinária,

Não há meio termo entre as duas alternativas. Ou a Constituição é uma lei fundamental, superior e não mutável pelos meio ordinários, ou ela é colocada no mesmo nível dos atos legislativos ordinários e, como estes, pode ser alterada ao gosto do poder legislativo. Se é correta a primeira alternativa, então é preciso concluir que um ato legislativo contrário à Constituição não é lei; se é correta, ao contrário, a segunda alternativa, então quer dizer que as Constituições escritas outra coisa não são que absurdas tentativas de limitar um poder que é, por sua natureza, ilimitável (CAPELETTI, 1984, p. 47-48).

A Suprema Corte - que se autonomeou órgão responsável pela interpretação maior da constituição - tem a trajetória marcada por avanços e recuos, prudências e ousadias, ativismo e auto composição. Barroso destaca que "a brevidade do texto constitucional e suas cláusulas gerais e abertas deram à Suprema Corte um papel privilegiado na interpretação e definição das instituições e dos valores da sociedade americana" (BARROSO, 2012, p. 42).

Marbury v. Madison foi a decisão que inaugurou o controle de constitucionalidade no constitucionalismo moderno, deixando assentado os princípios da supremacia da Constituição, da nulidade da lei que contrarie a Constituição e da competência do Poder Judiciário como intérprete final da Constituição, podendo invalidar os atos que lhe contravenham (BARROSO, 2012, p.32).

Percebe-se que o Controle Difuso, originado em Marbury v. Madison, é aquele em que "o poder de controle pertence a todos os órgãos judiciários de um dado ordenamento jurídico, que o exercitam incidentalmente, na ocasião da decisão das causas de sua competência" (CAPELETTI, 1984, p.67). 
Para Mendes, o Controle Difuso é um modelo que delega a todos os juízes a "qualidade" de declarar a (in)constitucionalidade de lei ou de ato do poder público. Segundo este autor, uma das características do modelo difuso, ou americano, do controle de constitucionalidade é a que "qualquer órgão judicial incumbido de aplicar a lei a um caso concreto tem o poder-dever de afastar a sua aplicação se a considerar incompatível com a ordem constitucional". (MENDES, 2012, p.1100).

Como bem destaca Barroso, este sistema de controle de constitucionalidade, no Brasil, existe desde a primeira constituição republicana, sem ter sofrido grandes alterações. Em terra brasilis todo e qualquer órgão do Poder Judiciário - do juiz recém-concursado até o Presidente do Supremo Tribunal Federal - têm "o dever de recusar aplicação às leis incompatíveis com a Constituição” (BARROSO, 2012, p.70).

A declaração de (in)constitucionalidade de uma lei produz efeitos, o que no controle difuso, via de regra, são meramente declarativos, pois a lei inconstitucional é contrária a norma superior (Constituição), e considerada absolutamente nula, e, por isso, ineficaz (CAPELETTI, 1984, p. 115). Esta declaração de inconstitucionalidade por "via de exceção" também terá eficácia ex tunc, retroativa, e será de caráter inter partes, ou seja, fica limitada ao caso concreto. Dessa forma, "o mero fato da inconstitucionalidade é causa de absoluta nulidade, por conseguinte, de ineficácia ipso jure das leis, antes mesmo que esta inconstitucionalidade seja declarada, solenemente e vinculatoriamente, pela sentença da Corte Constitucional competente" (CAPELETTI, 1984, p. 119).

Para o sistema americano de controle de constitucionalidade a lei inconstitucional é considerada absolutamente nula, pois é contrária a uma norma superior (Constituição), e por isso é ineficaz. Assim, o trabalho do Poder judiciário é apenas declarar uma nulidade pré-existente, o que enseja a aplicação de eficácia ex tunc.

Caso contrário a este sistema é o controle concentrado de constitucionalidade, onde prevalece o entendimento de que a lei inconstitucional é meramente anulável, e a decisão que reconheceu a inconstitucionalidade tem efeito constitutivo, e, como regra, eficácia ex nunc (BARROSO, 2012, p. 40).

Foi adotado pela primeira vez na Constituição da Áustria, de 1920, quando se criou uma Corte Constitucional, e aperfeiçoado via emenda, em 1929, quando aumentou os legitimados para instaurarem perante a Corte o processo de controle das leis (CAPELETTI, 1984, p. 106). Adota convicções doutrinárias de Hans Kelsen, seu idealizador, e seu desenvolvimento também é devido a ausência de 
stare decisis (força vinculante dos julgados do tribunal superior, com efeitos erga omnes, figura existente nos sistema do judicial reviw) dos tribunais europeus, nos quais vigoravam o sistema da civil law (CAPELETTI, 1984, p. 67-68-80).

A declaração de inconstitucionalidade "via de ação" tem caráter constitutivo, ou seja, de anulação, pois ocorrerá a cassação da lei. A lei será anulada tendo em vista ser inconstitucional. Entretanto, até esta declaração, a lei tem eficácia e validade (CAPELETTI, 1984, p.117). Isso porque Kelsen acreditava que a lei inconstitucional é anulável, pois até a declaração de inconstitucionalidade a lei era válida, e a declaração somente viria para anular $o$ ato (BARROSO, 2012, p.41). Segundo Kelsen,

Dentro de uma norma jurídica não pode haver algo como a nulidade, que uma norma pertencente a uma ordem jurídica não pode ser nula mas apenas pode ser anulável. Mas esta anulabilidade prevista pela ordem jurídica pode ter diferentes graus. Uma norma jurídica em regra somente é anulada com efeitos para o futuro, por forma que os efeitos já produzidos que deixa para traz permanecem intocados (KELSEN, 2003, p.306).

No sistema concentrado, também chamado de austríaco, não se declara a nulidade de uma lei, mas sim a anulabilidade. Assim, até a publicação da decisão da Corte, esta lei é válida e eficaz (CAPELETTI, 1984, p. 116). O controle por via principal é associado ao controle concentrado, mas, assim como ocorre com o controle incidental e o controle difuso, não são sinônimos, tampouco se confundem a fiscalização principal e concentrada (BARROSO, 2012, p.73).

Este modelo de controle (principal) independe de uma "lide tradicional", com partes, fatos, causa de pedir, pedido, pois é exercido "fora" de um caso concreto, já que seu objeto é a discussão da validade da lei ou de um ato do poder público. Este modelo não tutela direitos subjetivos, mas sim a "harmonia do sistema jurídico, do qual deverá ser eliminada qualquer norma incompatível com a Constituição" (BARROSO, 2012, p.73).

O Controle concentrado pode ser chamado de controle "principal", pois a constitucionalidade discutida pode ser arguida em um processo autônomo e/ ou principal, que tenha por objetivo sanar a própria inconstitucionalidade da lei. (MENDES, 2012, p.1098). Neste tipo de controle de constitucionalidade, o poder de controle se concentra em um único órgão judiciário. Além de concentrar a 
competência exclusiva para decidir questões de constitucionalidade à Corte Constitucional, a Constituição austríaca criou mecanismos para exercer este controle, isto é, para exercer o controle concentrado de constitucionalidade é necessário ingressar com um pedido especial, uma ação especial (CAPELETTI, 1984, p. 104).

Esta "ação especial”, necessária para a realização do controle principal, deve ser inteiramente desvinculada dos casos concretos, dos processos "comuns" (p. ex. processo civil e penal). Ou seja, para a declaração de (in)constitucionalidade via controle concentrado é necessário ingressar "em via de ação" no Poder Judiciário, mediante um adequado e autônomo recurso e com a propositura de adequado e autônomo processo à Corte Suprema (CAPELETTI, 1984, p. 104-105). Segundo Capeletti, o sistema do controle concentrado de constitucionalidade está baseado em uma doutrina da supremacia da lei e/ou da nítida separação dos poderes, com a exclusão de um poder de controle da lei parte dos juízes comuns (CAPELETTI, 1984, p.84).

Percebe-se então que originalmente a declaração de inconstitucionalidade via sistema austríaco de controle de constitucionalidade não retroage no tempo. Esta declaração terá efeitos ex nunc ou pro futuro, bem como terá caráter geral, ou seja, erga omnes, tornando a lei inconstitucional ineficaz para todos (CAPELETTI, 1984, p.118). O Controle Concentrado de constitucionalidade delega o julgamento de questões constitucionais a um órgão jurisdicional superior.

Com a adoção de ações individuais para a declaração de (in)constitucionalidade, este modelo acaba criando mecanismos específicos, como por exemplo, a atribuição de eficácia ex tunc (efeito retroativo), para o caso concreto, (MENDES, 2012, p.1099), com a declaração da inconstitucionalidade da lei desde o seu nascedouro, tornando nulos todos os atos dela derivados. Neste modelo, o juiz, ou tribunal, é um participante ativo no controle de constitucionalidade. (MENDES, 2012, p.1100).

Para Kelsen, existe a possibilidade de aplicação de efeitos retroativos a declaração de inconstitucionalidade, mas mesmo assim, não estar-se-á diante de uma norma nula, mas sim, anulável, pois ela foi válida até a sua declaração, ou seja, ela não era nula no início. Segundo este autor, "uma norma pertencente a uma ordem jurídica também pode ser anulada com efeito retroativo, por forma tal que os efeitos jurídicos que ela deixou atrás de si sejam destruídos" (KELSEN, 2003, p. 306).

Assim sendo, resta evidente que o controle de constitucionalidade é dividido entre o modelo difuso e o concentrado, o que acabou por ensejar o 
surgimento do modelo misto. (MENDES, 2012, p.1099). Este modelo de controle de constitucionalidade congrega os dois modelos de controle - concentrado e difuso - e, em geral, "defere-se aos órgãos ordinários do Poder Judiciário a prerrogativa de afastar a aplicação da lei não ações e processos judiciais" (MENDES, 2012, p.1100), o que é uma característica do Controle Difuso, mas "reconhece a determinado órgão de cúpula a competência para proferir decisões em ações de perfil abstrato ou concreto". (MENDES, 2012, p.1100).

Como se sabe, no Brasil vigora o Controle Misto de Constitucionalidade das leis e dos atos de governo, pois a (in)constitucionalidade pode ser arguida tanto em processo incidental, quanto em processo principal, utilizando o controle difuso ou concentrado, dependendo da forma que a questão chegou até o Poder Judiciário.

Tavares, em que pese não acreditar na existência de um modelo misto, pelo fato de acreditar que o modelo difuso e concentrado não podem simplesmente serem conjugados entre si, (2012, p. 252), reconhece que no Direito brasileiro, onde era originalmente admitido apenas o controle difuso, a partir da Constituição de 1988, cresceu a utilização do controle concentrado de constitucionalidade, sem, no entanto causar prejuízos ao difuso (TAVARES, 2012, p. 308).

Importante ressaltar que para a declaração de inconstitucionalidade das leis dos atos do poder público, a Constituição Federal exige a maioria absoluta dos votos dos membros do Supremo Tribunal Federal, ou do tribunal responsável pela declaração da inconstitucionalidade. Segundo o Artigo 97, in verbis, "somente pelo voto da maioria absoluta de seus membros ou dos membros do respectivo órgão especial poderão os tribunais declarar a inconstitucionalidade de lei ou ato normativo do Poder Público".

Ocorre que se trabalhando com o controle difuso e o controle concentrado de constitucionalidade, emerge especial atenção com a questão da modulação dos efeitos desta declaração, pois o ordenamento jurídico brasileiro consagra a eficácia ex tunc do direito estadunidense (judicial review), e também as eficácias ex nunc e pro futuro, oriundas da tradição austríaca. Ademais, o Poder Judiciário deve sempre buscar o chamado ato jurídico perfeito, pois como intérprete da Lei Maior, a perfeição de seus atos se torna indispensável.

Como dito anteriormente, a possibilidade de efeitos ex tunc existe no Brasil desde a primeira constituição republicana. Já as eficácias ex nunc e pro futuro, em que pese já virem sendo trabalhado a algum tempo pela jurisprudência 
e pelos costumes, ganham especial atenção a partir da redação do Artigo 27, da Lei 9.868/99.

\section{MODULAÇÃO NO CONTROLE DE CONSTITUCIO- NALIDADE}

Modulação é a prática do Supremo Tribunal Federal de reconhecer a inconstitucionalidade de determinado ato normativo, estabelecendo limites temporais à sua nulidade. Assim, geralmente a modulação implica na limitação dos efeitos temporais da declaração de inconstitucionalidade desviando-se da condição ortodoxa ex nunc ou ex tunc.

Uma vez reconhecido o desrespeito ao texto constitucional de uma lei ou de um ato de governo, a inconstitucionalidade pode ser declarada total ou parcialmente, isso porque os efeitos desta declaração podem ser restringidos no tempo, já que o ordenamento jurídico brasileiro consagra as hipóteses de fixação de efeitos ex tunc, ex nunc e pro futuro (MENDES, 2012, p. 1215).

Como bem destaca Barroso, a modulação pode ser declarada em quatro cenários diferentes, pelos quais o Poder Judiciário é provocado a agir. São eles a) a declaração de inconstitucionalidade em ação direta; b) a declaração de inconstitucionalidade em controle incidental; c) a declaração de constitucionalidade em abstrato; e d) a mudança de jurisprudência consolidada acerca de determinada matéria (BARROSO, 2012, p. 99).

Porém, a declaração da modulação pressupõe a existência de pelo menos um dos dois requisitos previstos no Artigo 27, da Lei n. ${ }^{\circ}$ 9.868/99, a saber, a) segurança jurídica; e b) excepcional interesse social.

Ao declarar a inconstitucionalidade da lei ou de atos normativos, o Supremo Tribunal Federal, poderá, por maioria de dois terços de seus membros, restringir os efeitos da declaração ou decidir que ela só tenha eficácia (ou, seja, é capaz de produzir efeitos (SILVA, 2004, p. 66)) a partir de seu trânsito em julgado ou de outro momento que venha a ser fixado, desde que presente pelo menos um dos dois requisitos.

Para se utilizar a modulação dos efeitos no controle de constitucionalidade, faz-se necessário conhecer o que significa os requisitos previstos no artigo 27 da Lei $\mathrm{n}^{\circ}$ 9.868/99, definindo-se, por exemplo, o que venha a ser as expressões como "Segurança Jurídica e Interesse Social.

Entretanto, chegar a uma conceituação de segurança jurídica e interesse social não vem sendo tarefa fácil, principalmente em relação ao segundo, pois 
pouco se encontra sobre a expressão interesse social na doutrina brasileira no âmbito do controle de constitucionalidade (ÁVILA, 209, p. 163). Para tanto, recorreu-se a doutrina brasileira sobre o tema para definir tais institutos. No ordenamento jurídico brasileiro a expressão interesse social surgiu no campo das desapropriações, com a edição da Lei n. ${ }^{\circ}$ 4.132/62. A Constituição Federal de 1988, em seu artigo 184, também traz a expressão para regular o mesmo assunto (ÁVILA, 2009, p. 163).

Nesse sentido, falar em interesse social não significa dizer o interesse geral do povo, nem o do Estado. O interesse social não é o interesse da Administração ou do Estado, mas sim da sociedade. O interesse social vem no sentido de beneficiar o interesse de certa classe social, a menos favorecida, que reivindica a desapropriação da propriedade privada e individual da terra em favor da coletividade (ÁVILA, 2009, p. 164).

Já a Segurança Jurídica nada mais é do que a "constância do Direito, para que as pessoas possam ter previsibilidade nas suas condutas e estabilidade nas suas relações jurídicas", tendo em vista que a norma deixa de ser um enunciado abstrato e passa a ser o produto da interpretação (BARROSO, 2012, p. 99).

Para Ana Paula Ávila, a previsibilidade, a antecipação das consequências e a ciência por parte do cidadão do ordenamento jurídico, são elementos fundamentais desse princípio. Para esta autora "importante aspecto desse princípio consiste no conjunto de condições que tornam possível as pessoas ter previsibilidade, isto é, o conhecimento antecipado e reflexivo das consequências diretas de seus atos e de seus fatos à luz da liberdade reconhecida". (ÁVILA, 2009, p. 147).

A autora entende que para que o cidadão possa "enxergar" a segurança jurídica, se faz necessário à obediência às normas predeterminadas. Nas palavras da autora, "a segurança jurídica é vivenciada pelo indivíduo quando lhe são proporcionadas condições para saber, ou poder saber, quais são as normas vigentes, assim como condições de ter fundadas expectativas de que elas se cumpram". (ÁVILA, 2009, p. 147).

O princípio da Segurança Jurídica contempla, entre outros aspectos, "a proteção da boa-fé e do indivíduo frente aos atos estatais de cunho pessoal e concreto, e a proteção da confiança do cidadão em atos de cunho geral, impessoal e abstrato". (ÁVILA, 2009, p. 152).

Em outras palavras, a autora quer dizer que os cidadãos necessitam ter confiança que os seus direitos, regulados por atos públicos, têm efeitos duradouros 
previstos na norma jurídica. Logo, para a efetivação deste princípio, Ávila destaca que é necessário a obediência de pelo menos três aspectos: a) proibição de leis retroativas; b) respeito a coisa julgada; e c) irrevogabilidade dos atos administrativos constitutivos de direito. (ÁVILA, 2009, p. 153).

Por fim, resta destacar que a segurança jurídica sempre é relacionada com a busca do ato jurídico perfeito. Sobre o ato jurídico perfeito, assim leciona Mendes,

A referência ao ato jurídico perfeito permite definir com maior clareza a lei aplicável à dadas situações jurídicas, que somente produzirão efeitos no futuro, eventualmente no regime de uma lei nova. (...) A alteração posterior não afeta o ato jurídico perfeito já efetivado. Nesse sentido, a alteração posterior não pode repercutir no plano de sua validade, tendo em vista o ato jurídico perfeito (MENDES, 2012, p. 406).

Vistos os requisitos autorizadores da modulação dos efeitos de uma decisão, cabe ver agora que efeitos a modulação produz. Como se sabe, a decisão que aplica a modulação é uma decisão que declarou a (in)constitucionalidade de uma lei ou de um ato de governo.

E sendo o Brasil um Estado Democrático de Direito onde a Constituição é o centro normativo de validade de todo o ordenamento jurídico, e cabendo ao Poder Judiciário a guarda e o preceito desta Constituição, inclusive com a declaração de nulidade dos atos de governo ou das leis que contrariarem o texto constitucional, o pensamento lógico é que a inconstitucionalidade atinja o nascedouro da lei ou do ato.

Seguindo a teoria de que toda a norma inconstitucional é nula, aplicamse efeitos ex tunc, fazendo com que o entendimento da Suprema Corte contido na decisão seja aplicado desde o surgimento da norma inconstitucional. E assim se posiciona o ministro Gilmar Mendes do Supremo Tribunal Federal ao fundamentar seu voto na ADI $2.791-\mathrm{ED} / \mathrm{PR}$,

Como regra geral, as decisões proferidas em sede de ação direta de inconstitucionalidade possuem eficácia "ex tunc" sendo nulo o ato impugnado, desde a sua origem. Excepcionalmente, a declaração de inconstitucionalidade poderá ter efeito "ex nunc", quando, por razões de segurança jurídica ou de relevante interesse social, se mostrar oportuno que seja fixado outro momento de eficácia, nos termos do Art. 27, da Lei n. ${ }^{\circ} 9.868 /$ 1999. 
Segue neste sentido a posição do ministro Celso de Mello, do Supremo Tribunal Federal, ao julgar a ADIQO 652/MA, em 02 de abril de 1992, que cumpriu com seu papel de guardião da Constituição ao assim proferir seu voto:

O repúdio ao ato inconstitucional decorre, em essência, do princípio que, fundado na necessidade de preservar a unidade da ordem jurídica nacional, consagra a supremacia da Constituição. (...) Atos inconstitucionais são, por isso mesmo, nulos e destituídos, em consequência, de qualquer carga de eficácia jurídica. (...) a orientação da jurisprudência do Supremo Tribunal Federal, de um lado, sublinha a nulidade plena do ato inconstitucional, e, de outro, proclama - a partir de sua absoluta ineficácia jurídica - o caráter retroativo da declaração judicial que reconhece sua incompatibilidade hierárquico-normativa com a Lei Fundamental.

Com o entendimento que a lei inconstitucional é nula e desconstituída de eficácia jurídica, o posicionamento do tribunal não poderia ser outro, senão declarar eficácia retroativa as suas decisões. No mesmo voto, o ministro Celso de Mello fundamenta a utilização de eficácia retroativa da decisão que vota pela inconstitucionalidade da lei,

A declaração de inconstitucionalidade de uma lei alcança, inclusive, os atos do passado com base nela praticados, eis que o reconhecimento desse supremo vício jurídico, que inquina de total nulidade os atos emanados do Poder Público, desampara as situações constituídas sob sua égide e inibe, ante a sua inaptidão para produzir efeitos jurídicos válidos - a possibilidade de invocação de qualquer direito.

Porém, existem situações que a realidade fática não suporta este tipo de efeitos, pois a inconstitucionalidade pode estar tão arraigada na sociedade, que a revogação de todos os atos decorrentes desta lei ou ato agora tido como inconstitucional poderia gerar grandes danos à sociedade ou ao Estado. Em certas situações, se torna inimaginável a quantidade de relações jurídicas que foram e ainda são reguladas por esses diplomas, e que seriam abaladas caso o Poder Judiciário aplique, friamente, a nulidade retroativa.

$\mathrm{Na}$ fundamentação de seu voto da ADI 4.009/SC, em 04 de fevereiro de 2009, o ex-ministro do Supremo Tribunal Federal Eros Grau, entendeu em fixar efeitos ex nunc à declaração de inconstitucionalidade, por entender que a declaração ex tunc geraria prejuízos e insegurança jurídica, 
Observo, contudo, que alguns dos preceitos atacados estão em vigência desde 1992. Dos efeitos ex tunc da declaração resultariam prejuízos e insegurança jurídica. Proponho a modulação dos efeitos da declaração de inconstitucionalidade, nos termos do disposto no artigo 27 da Lei n. 9.868?99, de modo que a decisão tenha eficácia ex nunc a partir da publicação do acórdão.

Como se vê, o ministro adotou cautela ao restringir os efeitos de sua decisão, pois entendeu ser melhor validar consequências pretéritas de uma lei declarada inconstitucional, do que retroagir os efeitos, e causar prejuízo ao Estado e a sociedade, correndo o risco de gerar insegurança jurídica.

Levando isso em consideração, o ordenamento jurídico brasileiro criou, a partir da redação do artigo 27 da Lei 9.868/99, a possibilidade de modulação com efeitos ex nunc, aplicando o novo entendimento a partir da decisão, e também a modulação com efeitos pro futuro, ou seja, o entendimento contido na decisão só terá validade a partir de um momento futuro, a ser fixado por esta mesma corte suprema. Nesse sentido, Barroso destaca que pela primeira vez foi positivada a atenuação da teoria da nulidade do ato inconstitucional, ao admitir que a declaração de inconstitucionalidade não retroagisse ao início da vigência da lei (BARROSO, 2012, p. 46).

Ávila entende que o referido artigo trouxe mudanças significativas em relação a restrição dos efeitos temporais da declaração de inconstitucionalidade, pois inovou ao permitir que as declarações do Supremo Tribunal Federal em abstrato (controle difuso) produzam efeitos ex nunc ou pro futuro. Com isso, continua a autora, criou-se um regime em que a retroatividade dos efeitos (ex tunc) é uma regra que deve conviver com as exceções (declaração ex nunc e pro futuro) (ÁVILA, 2009, p. 21-22).

Tido como regra, o efeito ex tunc é também conhecido como efeito “original". Original, porque durante décadas prevaleceu a orientação no Supremo Tribunal Federal de que a lei inconstitucional é nula de pleno e direito e desconstituído de qualquer eficácia jurídica, logo todos os atos realizados em decorrência desta lei, também o são, e, por isso, há necessidade de se declarar efeitos retroativos da decisão.

Já a possibilidade de aplicação de efeitos ex nunc em terra brasilis foi positivada com o advento da Lei n. ${ }^{\circ}$ 9.868/99 que regula a Ação Direta de Inconstitucionalidade e Ação Declaratória de Constitucionalidade, porém, essa nova lei trouxe pouca inovação ao que já vinha sendo praticado, pois a fixação 
de efeitos prospectivos já vinha sendo realizada pelo Supremo Tribunal Federal (ÁVILA, 2009, p. 48-49).

Com grande influência do ex-ministro Leitão de Abreu, o efeito ex nunc foi ganhando força dentro do Supremo Tribunal Federal. Em tempos que a aplicação de efeitos retroativos era a regra, mesmo sendo voto vencido em diversos julgados, o ministro fundamentava seu voto no sentido de que "a lei é um fato eficaz, ao menos antes da determinação da inconstitucionalidade, podendo ter consequências que não é lícito ignorar"2" (ÁVILA, 2009, p. 48).

Também a lei que possibilitou a aplicação de efeitos ex nunc permitiu que as decisões do Supremo Tribunal Federal declarando a inconstitucionalidade de uma lei ou de ato de governo produzam efeitos a partir de um momento que a Corte ache por bem fixar, dando vida, assim, ao denominado efeito pro futuro.

Para tanto, o Supremo Tribunal Federal vem adotando uma técnica de superação da jurisprudência denominada pure prospectivity, na qual o novo entendimento se aplica exclusivamente para o futuro, e não àquela decisão que originou a superação da antiga tese ${ }^{3}$.

Além das hipóteses até aqui tratadas, o controle difuso apresenta, no Brasil, outra forma de modulação dos efeitos da decisão. Com origens na tradição do judicial review, sistema que se adotou a Teoria da Nulidade onde o ato inconstitucional é considerado nulo, e por isso mesmo os efeitos que produziu devem ser desconstituídos desde a origem, o controle de constitucionalidade difuso consagra, via de regra, a declaração de efeitos retroativos ex tunc.

Diz-se via de regra, pois no Brasil vem ocorrendo aquilo está sendo chamado de abstrativização do controle difuso, o que segundo Streck, pode acarretar "uma nova concepção, não somente do controle da constitucionalidade no Brasil, mas também de poder constituinte, de equilíbrio entre os Poderes da República e de sistema federativo" (STRECK, 2013, p. 46). O que se quer dizer com a expressão abstrativização do controle difuso, é que características próprias do controle abstrato estão sendo aplicadas ao controle difuso.

O ministro Gilmar Mendes, do Supremo Tribunal Federal, ao fundamentar seu voto no Recurso Extraordinário n. ${ }^{\circ} 197.917 / \mathrm{SP}$, acena com a possibilidade de aplicação de efeitos ex nunc ou pro futuro, em via de controle concreto, se a situação fática assim o exigir, pois entende que "o controle difuso não se

${ }_{2} \mathrm{RE} \mathrm{n}^{\mathrm{o}}$ 79.343/BA, 31 de maio de 1977; RE $\mathrm{n}^{\circ}$ 93.356/MT, 24 de março de 1981.

3 ADI 4.029 / DF 
mostra incompatível com a doutrina da limitação dos efeitos". Para tanto, argumenta que nos Estados Unidos da América, sistema difuso mais tradicional do mundo, admite-se a mitigação dos efeitos da declaração de inconstitucionalidade.

Como se vê o Supremo Tribunal Federal tem o poder de aplicar os efeitos que entender ser cabível para cada caso concreto. Assim, a possibilidade, de aplicação de efeitos ex tunc, ex nunc e pro futuro, prevista no Artigo 27 da Lei 9.868/99, deve ser vista com cautela, pois a partir do evidente protagonismo judicial, herdado do(s) positivismo(s), o Poder Judiciário, que tem o papel de intérprete maior das leis e guardião da Constituição, vem tomando corpo um "movimento" institucional denominado (mesmo que não se tenha uma definição correta) de Ativismo Judicial, que traz consigo uma consequência maligna para o Direito, qual seja, a discricionariedade judicial.

\section{MODULANDO O CONTROLE DE CONSTITUCIONALIDADE NO SISTEMA DIFUSO - RECURSO EXTRAORDINÁRIO 197.917/SP}

A discussão envolve o julgamento pelo Recurso Extraordinário 197.917/ SP, que o Ministério Público Estadual interpôs contra o Município de Mira Estrela e a Câmara Municipal de Mira Estrela, município do interior de Estado de São Paulo.

O Ministério Público ajuizou ação civil púbica visando a redução do número de vereadores da cidade de onze para nove, pedindo ainda, a extinção dos mandatos dos dois vereadores que extrapolam o limite, e a devolução dos valores recebidos desde os dois primeiros candidatos eleitos além do limite de nove vereadores, sob a alegação de que a parágrafo único do artigo $6^{\circ}$ da Lei Orgânica do Município não obedece a proporção estabelecida pelo artigo 29, inciso IV, alínea 'a' da Constituição Federal.

O juiz de primeiro grau julgou parcialmente procedente a ação, reduzindo o número de vereadores, decretando a extinção dos dois mandatos que extrapolam o limite constitucional. Entretanto, o juiz indeferiu o pedido de devolução dos valores recebidos até a sentença, determinando apenas, a restituição do que eventualmente fosse recebido a partir da sentença. Em segundo grau de jurisdição a ação foi julgada improcedente, por entenderem os desembargadores que não ocorreu violação frontal e manifesta do preceito constitucional. Desta decisão foi interposto Recurso Extraordinário pelo 
Ministério Público Estadual, sustentando os mesmo argumentos aduzidos na inicial.

O Supremo Tribunal Federal, por maioria, proveu parcialmente o Recurso Extraordinário, restabelecendo, em parte, a decisão de primeiro grau, declarando inconstitucional o parágrafo único do artigo $6^{\circ}$ da Lei Orgânica 226, de 31 de março de 1990, do município de Mira Estrela, São Paulo, aplicando efeito pro futuro, para que a câmara de vereadores, após o trânsito em julgado, adote medidas para adequar sua composição, respeitados os mandatos em curso dos vereadores.

Mesmo se tratando de controle difuso de constitucionalidade, onde se adota a teoria da nulidade, o Supremo Tribunal Federal decidiu pela aplicação de efeitos pro futuro, oriundo do controle concentrado de constitucionalidade. A definição de aplicação de efeitos pro futuro se baseou, segundo o ministro Gilmar Mendes, em "um processo de complexa ponderação entre o princípio da nulidade e o princípio da segurança jurídica":

Não se nega, pois, o caráter de princípio constitucional ao princípio da nulidade da lei inconstitucional. Entende-se, porém, que tal princípio não poderá ser aplicado nos casos em que se revelar absolutamente inidôneo para a finalidade perseguida (casos de omissão; exclusão de benefício incompatível com o princípio da igualdade), bem como nas hipóteses em que a sua aplicação pudesse trazer danos para o próprio sistema jurídico constitucional (grave ameaça à segurança jurídica).

(...)

Desse modo, em muitos casos, há de se preferir a declaração de inconstitucionalidade com efeitos restritos à insegurança jurídica de uma declaração de nulidade.

(...)

A norma contida no Artigo 27 da lei 9.868, de 1999, tem caráter fundamentalmente interpretativo, desde que se estenda que os conceitos jurídicos indeterminados utilizados se revestem de base constitucional.(...) O que importa assinalar é que, consoante a interpretação aqui preconizada, o princípio da nulidade somente há de ser afastado se se puder demonstrar, com base numa ponderação concreta, que a declaração de inconstitucionalidade ortodoxa envolveria o sacrifício da segurança jurídica ou de outro valor constitucional materializável sob a forma de interesse social.

Por entender que a declaração retroativa de inconstitucionalidade acarretaria em inúmeros prejuízos, repercutindo em todo o sistema vigente, 
alcançando inclusive composições anteriores da Câmara Municipal, e atingindo a validade da deliberação da Câmara Municipal nos diversos projetos e leis aprovados, decidiu-se pelo efeito pro futuro.

Entende-se que o Supremo Tribunal Federal decidiu por aplicar efeitos profuturo, para preservar a atual composição da Câmara Municipal, os mandatos passados que foram regidos pela norma inconstitucional, bem como os inúmeros projetos e leis aprovados pela Câmara Municipal, inclusive os que já foram postos em prática.

Para o ministro César Peluso, em se tratando de controle de constitucionalidade, os fins justificam os meios. Isso porque o ministro entende que o importante é se chegar em um controle eficaz da constitucionalidade:

De fato, se a Constituição Federal legitima tal limitação no controle abstrato, não tem por que não legitimá-la no concreto, pois, no fundo, as técnicas de controle servem ambas, com caráter alternativo e consequências próprias, adequados a cada situação histórica, ao mesmíssimo propósito constitucional. A variedade dos instrumentos, ou dos métodos, não desnatura o fim, que é único, o controle eficaz da constitucionalidade das leis. A regra da nulidade, enfim, cede apenas a razoes de coerência sistemática e de segurança jurídica, ditadas por situações excepcionais.

Para o ministro Gilmar Mendes este caso demonstrou uma "plena e completa superação da intervenção do Senado", cumprindo a ele tão somente a função de emprestar mera publicidade à questão. Entretanto, esta argumentação não se estendeu pelo fato de que o caso em tela não há necessidade de suspender a execução da lei em todo o país (função do senado, que agrega eficácia ex nunc e erga omnes à decisão do Supremo Tribunal Federal), por se tratar de lei local.

Entende-se que a atuação do Poder Judiciário não deve ser guiada pela busca do "melhor fim", independentemente dos meios que são utilizadas para tanto. Acontece se espera do Supremo Tribunal Federal a presença de critérios jurídicos em suas decisões que justifiquem o direito posto em discussão.

O problema de atuar de maneira solipsista é que assim agindo o Poder Judiciário estará atuando de maneira arbitrária, uma vez que, se afastadas as Teorias da Norma, das Fontes e da Interpretação, o julgador estará empregando sua vontade, o que geraria o exercício da discricionariedade. Nesse sentido, Trindade e Morais ao apresentar a contribuição de Streck contra a 
discricionariedade implicam na busca de uma resposta adequada a constituição, isto é,

O direito produzido democraticamente exige decisões fundamentadas com base em princípios jurídicos. Esse apelo à normatividade dos princípios é feito para, diante do seu caráter intersubjetivo, impedir que preferências pessoais dos julgadores determinem os resultados das decisões judiciais (TRINDADE E MORAIS, 2011, p. 121).

Ao declarar efeitos pro futuro no controle difuso de constitucionalidade, mesmo com uma extensa fundamentação, estaria o Supremo Tribunal Federal seguindo a tradição da nulidade do ato jurídico declarado inconstitucional nos moldes do judicial review? Ou estaria inovando de acordo com sua conveniência? Essas perguntas parecem indicar uma postura ativista do Poder Judiciário, e, portanto, sem critérios constitucionais explícitos para definição da modulação dos efeitos das suas decisões que controlam a constitucionalidade posta em discussão.

\section{CONSIDERAÇÕES FINAIS}

A modulação da decisão que declara a inconstitucionalidade da lei ou de um ato de governo segue algum critério? Na existência de critérios, estaria o Supremo Tribunal Federal respeitando-o?

Com base nos referenciais bibliográficos pesquisados, buscou-se entender quais são os critérios para restringir os efeitos da decisão que declara a inconstitucionalidade de uma lei ou de um ato de governo, e, através de pesquisa jurisprudencial no site do Supremo Tribunal Federal, procurou-se na decisão selecionada se os ministros desta Suprema Corte obedecem aos critérios estabelecidos em lei.

Isso porque, a hipótese da pesquisa era descobrir se o Supremo Tribunal Federal poderia estar sendo ativista e discricionário na hora de restringir os efeitos de sua decisão, pois como a atividade de modular os efeitos da decisão é calcada nos critérios subjetivos da "segurança jurídica" e do "excepcional interesse social", abre-se espaço para a atuação discricionária dos ministros do Supremo Tribunal Federal, que podem utilizar a interpretação como um ato de vontade, o que não mais cabe em um Estado Democrático de Direito. 
Assim, o trabalho apresentou a superação do positivismo jurídico pelo constitucionalismo contemporâneo, bem como as formas de controle de constitucionalidade, a modulação e, ao final, a abstrativização do controle difuso de constitucionalidade.

Em primeiro momento, procurou-se demonstrar a superação histórica das teorias positivistas, frente a crescente necessidade de legitimação do Direito para se viver em um Estado Democrático de Direito. A partir de então, vive-se o chamado Constitucionalismo Contemporâneo, o qual deixa de ver o direito como um aglomerado de normas a serem aplicadas conforme a vontade (discricionariedade) do intérprete, e exige que o Direito posto em questão seja pronunciado através de uma decisão fundamentada. Para o Constitucionalismo Contemporâneo, a Constituição é o centro normativo, é a lei maior de todo o ordenamento jurídico. A Constituição Federal passa a ser o centro de validade de todo o ordenamento jurídico, na medida que impõe uma postura a ser adotada, principalmente por parte do Poder Judiciário.

A partir da existência de uma Constituição rígida e superior, começa-se a trabalhar a ideia do controle de constitucionalidade, pois se não existisse uma lei superior, não haveria como falar em controle de constitucionalidade, já que que estaria sendo posto em discussão duas normas do mesmo escalão.

O controle de constitucionalidade adotado no Brasil segue tanto as tradições do judicial review, através do sistema difuso de controle de constitucionalidade, com origem nos Estados Unidos da América, quanto as tradições europeias, através do controle concentrado de constitucionalidade, também conhecido como sistema austríaco. Segundo a tradição kelseniana do controle concentrado de constitucionalidade, antes da declaração de inconstitucionalidade da lei, ela existiu e foi válida, portanto, seus efeitos devem ser mantidos. Já a tradição do judicial review, adota o controle de constitucionalidade difuso, sendo que a lei declarada inconstitucional é nula de pleno e direito, e todos os atos dela decorrentes devem ser declarados nulos.

Além disso, no Brasil ocorre o que é chamado de abstrativização do controle difuso, pois o Supremo Tribunal Federal vem aplicando efeitos inerentes ao controle de constitucionalidade abstrato ao controle concreto.

A partir de então, surge o problema da pesquisa, pois como será aplicada a modulação se o sistema brasileiro consagra a tanto a teoria da nulidade, quanto a da anulabilidade? Qual o efeito a ser declarado, ex tunc, ex nunc, pro futuro, diante da inconstitucionalidade de uma lei? Qual será o critério utilizado para aplicar a modulação, sem ser ativista e discricionário? 
No Brasil, o controle de constitucionalidade difuso, existe desde a primeira constituição republicana, sem ter sofrido grandes alterações. Do sistema difuso, o controle de constitucionalidade brasileiro adotou a declaração de efeitos retroativos como regra, mesmo quando diante de controle concentrado, o que pode ser observado com o Artigo 27 da Lei 9.868/99, que trata como exceção a aplicação de efeitos ex nunc ou pro futuro. Assim sendo, o critério utilizado na hora de aplicar a modulação dos efeitos da decisão é a existência da "segurança jurídica" ou do "excepcional interesse social".

Com base nestes critérios que os magistrados decidem qual é o efeito a ser aplicado em cada caso concreto. Também é com base nestes critérios que ocorre a abstrativização do controle difuso, aplicando efeitos ex nunc ou pro futuro, a este tipo de controle, deixando o texto da Constituição de lado, para afastar a competência do Senado Federal.

\section{REFERÊNCIAS}

\section{ÁVILA, Ana Paula. A modulação de efeitos temporais pelo STF no controle de constitucionalidade. Ponderação e regras de argumentação para a interpretação conforme a constituição do artigo 27 da lei $\mathbf{n}^{\mathbf{0}}$ 9.868/99. Porto Alegre: Livraria do Advogado Editora, 2009.}

BARROSO, Luís Roberto. O controle de constitucionalidade no direito brasileiro. 6. ed. São Paulo: Saraiva, 2012.

BRASIL. Supremo Tribunal Federal. Recurso Extraordinário n. 197.917/SP. Recorrente: Ministério Público Estadual. Recorridos: Município de Mira Estrela e Câmara Municipal de Mira Estrela. Relator: Maurício Corrêa. Brasília, 06 de junho de 2002. Disponível em: $<$ http://redir.stf.jus.br/ paginadorpub/paginador.jsp?docTP $=\mathrm{AC} \& \operatorname{doc} \mathrm{ID}=235847>$ Acesso em: 04 out. 2012.

CAPELETTI, Mauro. O controle judicial de constitucionalidade das leis no direito comparado. Tradução de Aroldo Plinio Gonçalves. Porto Alegre, Fabris, 1984.

KELSEN, Hans. Teoria Pura do Direito. Tradução de João Baptista Machado. 6. ed. São Paulo: Martins Fontes, 2003. 
MENDES, Gilmar Ferreira. Curso de Direito Constitucional. 7. ed. São Paulo: Saraiva, 2012.

SILVA, José Afonso da. Aplicabilidade das normas constitucionais. 6 . ed. São Paulo: Malheiros Editores, 2004.

STRECK, Lenio Luiz. Jurisdição Constitucional e Hermenêutica. $2^{\mathrm{a}}$ ed. Forense, 2004.

STRECK, Lenio Luiz; ROCHA, Leonel Severo (orgs.). Constituição, sistemas sociais e hermenêutica. Porto Alegre: Livraria do Advogado Editora, 2005.

STRECK, Lenio Luiz. Verdade e consenso. Constituição, Hermenêutica e Teorias Discursivas da Possibilidade à necessidade de respostas corretas em Direito. 3. ed. Rio de Janeiro: Lumen Juris, 2009.

STRECK, Lenio Luiz; LIMA, Martonio Mont'Alverne Barreto; OLIVEIRA, Marcelo Andrade Cattoni de. A Nova Perspectiva do Supremo Tribunal Federal Sobre o Controle Difuso: Mutação Constitucional e Limites da Legitimidade da Jurisdição Constitucional. Revista Argumenta, Jacarezinho - PR, n. 7, p. 45-68, Fev. 2013. ISSN 2317-3882. Disponível em: $<$ http://seer.uenp.edu.br/index.php/argumenta/article/view/72/72>. Acesso em: 13 Jul. 2015.

TASSINARI, Clarissa. ATIVISMO JUDICIAL: Uma análise da atuação do Judiciário nas experiências brasileira e norte-americana.

Dissertação apresentada ao Programa de Pós-Graduação em Direito da Área das Ciências Jurídicas da Universidade do Vale do Rio dos Sinos, como requisito parcial para a obtenção do título de Mestre em Direito.São Leopoldo, 2012.

TAVARES, André Ramos. Curso de Direito Constitucional, 10. ed. São Paulo: Saraiva, 2012.

TRINDADE, André Karam; MORAIS, Fausto Santos de. Ensaio sobre a Crítica Hermenêutica do Direito - Reflexões sobre o pensamento jurídico de 
Lenio Streck. In: Revista do Instituto de Hermenêutica Jurídica. v. 9. n. 9/10, jan./dez. 2011, p. 107 a 128.

TRINDADE, André Karam. Garantismo versus neoconstitucionalismo: os desafios do protagonismo judicial em terrae brasilis. In: FERRAJOLI, Luigi; STRECK, Lenio Luiz; TRINDADE, André (Orgs.). Garantismo, hermenêutica e (neo)constitucionalismo: um debate com Luigi Ferrajoli. Porto Alegre: Livraria do Advogado, 2012, p. 231-253.

Artigo recebido em: 20/07/2015 Aprovado para publicação em: 01/12/2015

Como citar: CORREIO, Bruno Ortigara Dellagerisi. MORAIS, Fausto Santos de. Modulação e abstrativização do efeito difuso: estudo de caso. Revista do Direito Público. Londrina, v.10, n.3, p.155-180, set/dez.2015. DOI: 10.5433/ 1980-511X.2015v10n3p180. ISSN: 1980-511X. 